\title{
PENGELOLAAN KAWASAN EKOWISATA BERBASIS MASYARAKAT SERTA IMPLIKASINYA TERHADAP KETAHANAN MASYARAKAT DESA SUKARARA
}

\author{
M Sunu Probo Baskoro ${ }^{1^{*}}$ \\ ${ }^{1}$ Kantor Berita Antara Lantai 19-20 Wisma Antara Jl. Medan Selatan No. 17 Jakarta, Indonesia. \\ *E-mail: sunu.dhadho@gmail.com
}

\begin{abstract}
Masyarakat di Desa Sukarare Lombok Timur Nusa Tenggara Barat berperan aktif dalam mengembangkan potensi desa Sukarare yakni mengembangkan kekayaan kearifan local berupa adat istiadat dan seni budaya. Pengembangan yang mereka lakukan adalah menjaga segala bentuk orisinalitas bangunan fisik rumah adat, upacara-upacara adat serta menjaga tradisi yang dilestarikan turun menurun seperti kewajiban menenun bagi kaum wanita sebelum bernajak dewasa. Masyarakat desa Sukarare juga berperan aktif berpartisipasi dalam semua kegiatan di Desa Sukarare seperti partisipasi tenaga, partisipasi harta benda, partisipasi ketrampilan, partisipasi kemahiran, serta partisipasi social. Partisipasi itu diberikan dalam rangka kontribusi yang masyarakat berikan dalam mengelola Kawasan Ekowisata Desa Sukarare Lombok Timur Nusa Tenggara Barat. Penelitian ini dilakukan guna mengetahui bagaimana partisipasi masyarakat dalam mengelola kawasan Ekowisata Desa Sukarare serta implikasinya terhadap ketahanan masyarakat desa khususnya Desa Sukarare Lombok Timur. Penelitian ini dilakukan dengan metode wawancara dan observasi lapangan dan dianalisa dengan metode deskriptif kualitatif. Pengembangan Ekowisata ini pada akhirnya mampu meningkatkan ketahanan masyarakat desa, social kemasyarakatan, pelestarian alam, pelestarian adat istiadat serta budaya.
\end{abstract}

Kata kunci : Pengelolaan Kawasan Ekowisata, Ketahanan Masyarakat Desa, Pelestarian adat istiadat, Pelestarian Budaya, Partisipasi Masyarakat 


\section{PENDAHULUAN}

Permasalah yang dihadapi oleh Negara-negara berkembang adalah begitu banyaknya desa-desa yang miskin dan terbelakang. Pernyataan ini sesuai dengan Tesis yang dilakukan oleh Schumacher $(1979 ; 162)$ yang menyatakan bahwa persoalan pokok yang dihadapi Negara-negara berkembang terletak pada dua juta desa yang miskin dan terbelakang. Schumacher berpendapat bahwa selama beban hidup di pedesaan tidak dapat diringankan, maka masalah kemiskinan di dunia ini tidak dapat diselesaikan, dan mau tidak mau pasti akan lebih memburuk.

Dalam membangun desanya, masyarakat desa biasanya seringkali menunggu bantuan dan uluran tangan dari pihak luar desa. Inisiatif membangun desa itu bukanlah dating dari masyarakat desa itu sendiri. Situasi yang seperti inilah yang membuat masyarakat desa semakin tergantung dengan masyarakat luar desa. Bahkan situasi akan menjadi lebih buruk bila tidak ada bantuan bagi desa maka penduduk desa akan pergi meninggalkan desa guna mencari penghasilan.
Suatu kondisi menarik terjadi di Desa Sukarare Lombok Timur Nusa Tenggara Barat, ketika masyarakat asli Lombok mulai mencoba peruntungan dengan mencari kerja ke kota khususnya ke pulau Bali, sejumlah masyarakat di Desa Sukarare Lombok Timur Nusa Tenggara Barat mencoba untuk mengelola desanya menjadi Kawasan Ekowisata. Pemilihan konsep Ekowisata bagi Kawasan Desa Sukarare dikarenakan konsep Ekowisata memiliki karakteristik. Karakteristik itu menurut Nugroho (2011; 3) karena Ekowisata mengedepankan konservasi lingkungan, kesejahteraan penduduk local dan menghargai budaya local. Ekowisata bukan menjual destinasi tetapi menjual filosofi sehingga ekowisata tidak akan mengenal kejenuhan pasar (Fandeli 2000; 8).

Dengan demikian, ekowisata dianggap tepat untuk dikembangkan di kawasan desa Sukarare karena dianggap apresiasinya terhadap lingkungan, baik lingkungan alam ataupun social budayanya. Awalnya masyarakat merasa kesulitan untuk mengembangkan model kawasan ekowisata di Desa Sukarare. Hal ini 
disebabkan kurangnya pengetahuan masyarakat dan belum adanya bantuan dari Pemerintah baik secara pendidikan dan pengetahuan ataupun secara finansial.

Awalnya, masyarakat tidak mengetahui arti dari ekowisata, sebagaimana ekowisata didefinisikan sebagai perjalanan wisata yang bertanggung jawab ke suatu destinasi dengan tujuan untuk mengkonservasi alam serta meningkatkan kesejahteraan masyarakat local. Ada perbedaan yang cukup kentara antara ekowisata dengan wisata berbasis alam. Pariwisata alam hanya melakukan perjalanan ke tempat-tempat alami sedangkan ekowisata, secara langsung memberikan manfaat bagi lingkungan, budaya dan ekonomi masyarakat local.

Untuk mengembangkan sebuah kawasan Ekowisata diperlukan peran Pemerintah yang bekerja sama dengan penduduk local. Salah satu hal yang harus dilakukan Pemerintah dalam mengembangkan sebuah kawasan ekowisata adalah membuat kebijakan pariwisata. Secara sederhana kebijakan pariwisata dapat diartikan sebagai, kebijakan yang mengidentifikasi sasaran-sasaran serta tujuan-tujuan yang membantu agent dalam proses perencanaan industry pariwisata (Funnel 2008; 134)

Pemerintah sebagai pemutus kebijakan bergandengan dengan masyarakat dalam mengembangkan kebijakan pariwisata yang berwawasan manajemen lingkungan. Langkah yang dilakukan diantaranya mengulas project kawasan ekologi, merencanakan program dari sudut pandang lingkungan, meningkatkan kapasitas masyarakat local dalam menguasai isu-isu lingkungan terutama terkait pembangunan daerah-daerah tujuan wisata serta mengintegrasikan pengembangan wisata dengan kebijakan manajemen lingkungan pada tingkat local, kawasan ataupun secara nasional (Funnel, 2008;135)

Ekowisata berbasis masyarakat merupakan usaha pariwisata yang menitikberatkan peran aktif komunitas. Hal ini dikarenakan masyarakat local yang meniliki pengetahuan tentang alam serta budaya yang menjadi potensi dan nilai jual sebagai daya tarik wisata sehingga keterlibatan masyarakat menjadi mutlak. Ekowisata berbasis masyarakat dapat menciptakan kesempatan kerja bagi 
masyarakat local dan mengurangi kemiskinan, dimana penghasilan ekowisata adalah dari jasa-jasa wisata untuk turis, seperti ongkos transportasi, pemandu wisata, penginapan, dan menjual kerajinan masyarakat.

Pada akhirnya, ekowisata membawa dampak positif terhadap pelestarian lingkungan, kearifan local dan pelestarian budaya masyarakat setempat. Pelestarian budaya local dan kearifan local secara tak langsung juga menumbuhkan jati diri dan rasa bangga diantara penduduk setempat. Hal ini seiring dengan meningkatnya kegiatan ekowisata.

\section{METODOLOGI}

Penelitian ini adalah penelitian kualitatif dengan melakukan pendekatan fenomenologis, dimana peneliti berusaha menggali informasi dan data dari penduduk asli desa Sukarare Lombok Timur Nusa Tenggara Barat. Untuk teknik pengumpulan data, peneliti menggunakan tenik wawancara mendalam dan observasi langsung di desa Sukarare. Peneliti menyempatkan dating ke desa Sukarare Lombok Timur Nusa Tenggara Barat pada medio 25-27 April 2016. Peneliti juga melakukan diskusi kelompok terarah, pertemuan antar individu ini merupakan kegiatan untuk melakukan verifikasi data dan perumusan strategi di tingkat desa. Hal terakhir yang dilakukan oleh peniliti selama penelitian adalah dengan melakukan dokumentasi. Teknik ini dilakukan untuk mengkaji dan menganalisa berbagai data, dokumen serta arsip yang berkaitan dengan kawasan ekowisata Desa Sukarare Lombok Timur Nusa Tenggara Barat.

\section{HASIL DAN PEMBAHASAN}

Desa Sukarare merupakan sebuah desa yang berada di kecamatan Sakra barat, Kabupaten Lombok Timur, Propinsi Nusa Tenggara Barat. Desa ini terbagi dalam lima dusun, yakni Dusun Tangar, Dusun Sukarara Selatan, Dusun Sukarara Utara, Dusun Repok dan Dusun Sukawangi.

Desa ini memiliki penduduk kurang lebih 6.033 jiwa pada 2014. Mayoritas penduduknya bekerja sebagai petani. Desa Sukarara masuk pada derah topografi datar dengan ketinggian 300400 DPL/Meter. Curah hujannya 1.190 dengan suhu udara 25-30. Adapun untuk luasan wilayahnya 544,58 $\mathrm{Ha}$. Batas-batas desa dan jarak antara 
tempuhnya sebagai berikut:

1. Sebelah utara berbatasan dengan Desa Suwangi Kecamatan Sakra dan Desa Pejaring Kecamatan Sakra Barat

Buruh Tani 1294 Jiwa, pedagang 88 Jiwa, PNS/TNI/Polri 10 Jiwa, Montir/sopir 14 Jiwa, Tukang Batu/Tkang Kayu 162 Jiwa, Guru 25 Jiwa, Karyawan Swasta 8 Jiwa, Pengrajin 20 Jiwa dan lainnya 6 Jiwa.

2. Sebelah Timur berbatasan dengan Desa Gunung Rajak Kecamatan Sakra dan Desa Pejaring Kecamatan Sakra Barat

3. Sebelah Selatan berbatasan dengan Desa Rensing Kecamatan Sakra Barat dan Desa Lekor Kabupaten Lombok Tengah Untuk tingkat pendidikan warga, Desa Sukarara tergolong desa yang menengah disbanding dengan desadesa lainnya di Kabupaten Lombok Timur, hal ini dilihat dari sebaran penduduk berdasarkan tingkat pendidikannya sebagai berikut:

1. Pasca Sarjana berjumlah 3 Orang

4. Sebelah Barat berbatasan dengan Desa Saba kecamatan Lombok Tengah

2. Sarjana 61 Orang

3. Diploma III berjumlah 12 Orang

5. Jarak tempuh ke ibukota kecamatan $3 \mathrm{KM}$

4. SMA Sederajat berjumlah 505 Orang

6. Jarak Tempuh ke Ibukota Kabupaten 15 KM

7. Jarak Tempuh Kota Propinsi $50 \mathrm{KM}$

5. SMP Sederajat 877 Orang

6. SD/MI berjumlah 1492 Orang

7. Tidak Tamat SD/MI sebanyak 735 Orang

8. Buta Huruf sebanyak 1178.

Adapun Jumlah penduduknya sebanyak 6033 Jiwa dengan Jumlah Laki-laki 3015 dan Perempuan 3018. Jumlah KK 1842 dan 100\% beragama Islam. Untuk mata pencaharian penduduk sebagian besar menjadi Petani dengan jumlah 2015 Jiwa,

Dari data tersebut diatas, ditemukan bahwa mayoritas penduduk Desa Sukarara hanya menamatkan pendidikan pada tingkat SD dan buta Huruf. Kenyataan yang cukup memprihatinkan ketika di saat yang 
bersamaan program pemerintah justru sedang berupaya mengurangi angka warga yang buta huruf.

Untuk Perekonomian warga Desa Sukarara terdapat pasar tradisional 1 unit, Kios/ warung sebanyak 37 unit dan indutri Menengah 6 Unit. Dari kondisi pendidikan dan ekonomi selanjutnya menjadi cermin untuk basis produksi warga Desa Sukarara. Untuk kondisi pertanian terutama pada Padi dan Palawija, sebagian besar warga menggunakan luas areal lahannya untuk menanam padi yakni seluas $362,78 \mathrm{Ha}$, sementara untuk Kacang Kedelai seluas 6,42 Ha dan Cabai 15,40 Ha. Untuk perkebunan sendiri, warga desa Sukarara secara $100 \%$ menggunakan lahannya guna menanam tembakau dengan luasan lahan 329, $24 \mathrm{Ha}$.

Khusus mengenai kondisi perekonomian di desa Sukarara tida terlepas juga dengan pengaruh perekonomian global. Sehingga walaupun ketersediaan lahan yang begitu luas untuk bertani, akan tetapi maslaah pemasaran dan biaya produksi yang besar membuat petani banyak menyewakan lahannya dan kemudian mereka menjadi buruh tani. Terdapat juga kepemilikan tanah luas yang dimiliki perseorangan sehingga dari kondisi tersebut angka buruh tani sangat banyak. Hal ini berarti nasib perekonomian warga setempat bergantung pada musim panen atau 2-3 kali setahun. Sementara itu, para pemilik lahan terutama yang menanam tembakau beberapa waktu lalu juga banyak mengalami kerugian, sehingga membuat mereka berhutang yang melebihi kuasanya.

Dalam adat istiadat Desa Sukarara juga mewajibkan anak-anak perempuan mereka untuk pandai menenun. Latihan menenun telah dilakukan oleh kaum perempuan warga desa Sukarara sejak mereka berumur enam tahun hingga dewasa sampai mereka tak mampu lagi menenun. Hal ini menjadi kewajiban dikarenakan sebagai bekal ketrampilan bagi kaum perempuan di Desa Sukarara. Bila kewajiban ini tidak dilaksanakan oleh perempuan di desa Sukarara maka perempuan itu dilarang untuk menikah. Dari kondisi tersebut, sabagai salah satu alternative ekonomi yang dibangun oleh warga, keputusan untuk bermigrasi dan bekerja diluar negeri menjadi suatu pilihan yang selanjutnya menjadi tradisi sendiri bagi warga. 
Desa Sukarara termasuk Desa yang masih sangat kuat memegang adat dan tradisi nenek moyangnya. Bersama desa tua lainnya keberadaan desa ini menjadi daerah penyuplai kebudayaan untuk daerah, seperti yang tergambar pada jumlah kelompok Budaya yang berjumlah 8 Kelompok yang terdiri dari kelompok Gendang Beleq, Cilokaq dan Kasidah dan Kelompok Tradisi sebanyak 15 Kelompok yang terdiri dari Kelompok Banjar Kematian, Yasinan, Hiziban dan Arisan.

Selain menjaga kelestarian alat-alat budaya dan kelompoknya, tradisi yang kuat pada hubungan kekeluargaan pun juga masih lekat. Ini ditandai dengan kekhasan acara-acara keluarga atau even kampung yang digelar pada setiap perayaan hari besar. Salah satu tradisi yang masyarakat Sukarara jaga hingga kini adalah tradisi menenun. Tradisi menenun ini dilakukan oleh seluruh perempuan yang tinggal di Desa Sukarara. Menenun menjadi hal yang wajib dilakukan oleh semua perempuan di Desa Sukarara. Menenun dilakukan oleh perempuan yang sudah berusia sepuluh tahun hingga perempuan dewasa.
Kewajiban menenun ini didasari atas pekerjaan yang terbatas di kawasan Lombok Timur. Kegiatan bertani yang tidak dilakukan setiap hari membuat perempuan di Desa Sukarara menenun saat waktu senggang. Kegiatan menenun bagi perempuan yang berumur sepuluh tahun, biasanya dimulai dengan menenun kain-kain yang kecil dengan motif-motif yang mudah.

Penenun di Desa Sukarara berjumlah tiga ribu orang, tingkatan yang paling mahir menenun adalah mereka yang berusia 16 tahun. Mereka merupakan generasi produktif dalam menghasilkan kain-kain tenun desa Sukarara Lombok Timur Nusa Tenggara Barat. Selain kegiatan menenun, penduduk desa Sukarara juga menjaga keaslian rumah tinggal mereka. Rumah tinggal mereka bernama Bale Tani. Bale berarti rumah dan Tani berarti adalah bertani yang merupakan profesi kebanyakan masyarakat desa Sukarara. Masyarakat Desa Sukarara juga hingga kini masih menjaga upacara-upacara adat mereka.

Pengelolaan Kawasan Ekowisata Berbasis Masyarakat

Dalam mengelola kawasan ekowisata desa Sukarara, masyarakat desa atau 
local mengerjakannya dengan swadaya. Maksud dari pengelolaan swadaya adalah para warga desa selalu bermusyawarah dalam memutuskan permasalahan yang terjadi di desa Sukarara. Local guide yang merupakan warga asli desa Sukarara tidak memiliki jam kerja yang pasti. Mereka secara bergantian ketika bertani, menjadi local guide bagi wisatawan dan serta menjadi sales dari kain-kain hasil tenunan warga desa Sukarara.

\section{Pengelolaan Lokal Guide}

Total lokal guide di Desa Sukarara berjumlah 26 orang, namun yang aktif dalam memberikan arahan kepada wisatawan hanya 15 orang. Dalam melaksanakan kegiatannya para local guide ini saling bergantian. Jika diantara mereka bertani maka yang lainnya menjadi lokal guide bagi wisatawan. Nurite salah seorang local guide menyatakan bahwa dalam pengelolaan jam kerja bagi local guide tidak ditentukan. Untuk menyediakan berbagai kebutuhan pokok warga desa seperti rumput pakan ternak, bertani, semua dilakukan secara bermusyawarah dan diputuskan oleh kepala adat/suku.
Nurite juga menjelaskan bahwa pengelolaan dana untuk desa juga bergantung dari donasi para wisatawan yang dating. Buku tamu disediakan saat wisatawan dating untuk mengisinya dan memberikan donasi bagi warga desa. Dari sinilah semua pembiayaan bagi operasional desa adat. Biasanya dana itu digunakan untuk memperbaiki rumah-rumah adat yang rusak.

\section{Pemasaran Kain Tenun}

Dalam menentukan pemasaran dari hasil tenunan, para warga desa membentuk suatu koperasi. Desa Sukarara memiliki enam koperasi yang memasarkan kain hasil tenunan warga desa. Mereka juga memikirkan untuk berpromosi desa mereka melalui pameran pariwisata dan pameran kerajinan. Untuk cara pengumpulan dari penenun, disetiap kampong memiliki satu orang pengumpul kain hasil tenun. Orang inilah yang nantinya akan berkeliling di setiap kampong untuk mengumpulkan kain hasil tenunan. Setelah terkumpul, kain-kain itu akan dipasarkan melalui koperasikoperasi.

Koperasi kampong juga tidak dikelola oleh pemerintah desa melainkan oleh 
seseorang yang dipercaya oleh warga kampong. Saat ini ada delapan belas pengurus koperasi kampong yang memasarkan kain-kain tenun desa Sukarara. Untuk promosi keluar pulau Lombok, Koperasi kampong akan bekerjasama denga Dinas Pemerintah Daerah Propinsi Nusa Tenggara Barat. Hingga saat ini, koperasi kain tenun Desa Sukarara telah berhasil mengikuti pameran kerajinan daerah di beberapa kota besar di Indonesia, diantaranya adalah di kota Jakarta.

\section{Pelatihan Ketrampilan Menenun}

Dalam meningkatkan keterampilan menenun, warga melakukannya dengan swadaya. Warga desa Sukarara belajar menenun secara turun-temurun, mereka tidak memiliki guru selain orang tua-orang tua mereka. Bahkan Pemerintah Daerah Kabupaten Lombok Timur meminta seorang warga dari Desa Sukarara untuk menjadi pengajar di Sekolah Dasar bidang ketrampilan menenun. Walaupun tidak menjadi pengajar tetap, tetapi kegiatan mengajar menenun di sekolah dasar ini secara rutin dilakukan setiap seminggu sekali.

Perempuan muda di desa Sukarara sudah diajarkan menenun semenjak umur sepuluh tahun. Kegiatan menenun dilakukan setelah pulang dari sekolah. Perempuan muda desa Sukarara berlatih menenun di rumahrumah mereka. Orang tua mereka berperan sebagai mentor dalam menenun. Mereka biasanya belajar menenun hingga sore hari. Dalam melatih perempuan-perempuan muda menenun pun warga desa Sukarara sudah memiliki tahapan-tahapan. Hal ini sebagaimana dijelaskan oleh local guide di desa Sukarara bahwa untuk tahap pertama pelatihan menenun tanpa motif alias polos. Ukuran kainnya pun berbeda, untuk pemula menenun kain dengan ukuran yang lebih kecil.

Tingkat kesulitan menenun pun semakin meningkat seiring dengan peningkatan ketrampilan dan keahlian dari penenun. Penenun dikatakan ahli jika sudah mampu menenun dengan motif Subhanalle, motif yang menurut warga desa Sukarara merupakan motif yang paling sulit. Hal ini dikarenakan menenun dengan benang emas dan motif yang tingkat kesulitannya sangat tinggi.

\section{Pembiayaan Desa Adat}

Untuk membiayai Desa Adat seperti, memperbaiki fisik rumah adat yang 
rusak, maka warga desa Sukarara melakukannya secara swadaya. Warga desa urunan dalam menyediakan dana perbaikan rumah-rumah adat yang rusak. Warga Desa memiliki dana dari hasil menjadi local guide, menjual kerajinan berupa kain tenun, menyewakan penginapan dan kunjungan wisatawan ke desa adat. Suku yang mendiami Desa Sukarara adalah Suku Sasak, dimana mereka dipimpin oleh seorang kepala adat atau suku. Ketika didapati ada bagian fisik dari desa adat yang mengalami kerusakan, maka warga desa akan bermusyawarah untuk menyelesaikan persoalan itu. Keputusan diambil oleh kepala Suku dan pengerjaan perbaikan fisik yang rusak dikerjakan secara bergotong royong.

Implikasinya terhadap Ketahanan Masyarakat Desa Sukarara

Adapun implikasinya bagi Ketahanan Masyarakat Desa Sukarara adalah, pertama, terhadap ketahanan perekonomian masyarakat desa Sukarara. Berkembangnya kawasan ekowisata desa Sukarara menjadi pendorong terangkatnya perekonomian warga desa.
Peningkatan terjadi dalam berbagai aspek, diantaranya adalah, aspek jasa, aspek budaya, seni, perdagangan, dan ketrampilan. Pengembangan kawasan ekowisata juga memunculkan pedagang kuliner, jasa transportasi, rumah makan, jasa penginapan dan warung. Selain terjadi peningkatan dalam sector ekonomi, pengelolaan kawasan ekowisata di desa Sukarara juga membuka lapangan-lapangan kerja baru. Lapangan kerja itu diantaranya adalah menjadi local guide, menjadi anggota koperasi, menjadi sales dari kain tenun hasil menenun warga desa Sukarara dan menjadi pelaksana pameran dari hasil kerajinan warga desa Sukarara.

Implikasinya terhadap social kemasyarakatan bagi warga Desa Sukarara diantaranya adalah penguatan social kemasyarakatan diantara warga desa. Dimana lembaga adat semakin kuat dalam pengambilan kebijakan diantara masyarakat. Sifat gotong royong diantara warga desa juga semakin baik. Hal ini ditandai dengan pola pemecahan setiap permasalahan yang ada, selalu dilakukan secara musyawarah dan diputuskan oleh kepala adat/suku. 
Implikasinya terhadap pelestarian lingkungan, warga desa Sukarara secara paham dan mengerti saat ini lebih menjaga lingkungan desanya. Pola hidup masyarakat hingga kini tetap berwawasan lingkungan dengan melakukan perlindungan dan pelestarian terhadap alam.

Implikasinya terhadap tingkat urbanisasi. Semenjak kawasan desa Sukarara dikelola secara ekowisata yang tentunya sangat memberi manfaat bagi warga desa, maka saat ini sangat jarang ditemui warga desa yang pergi keluar negeri untuk mencari nafkah. Warga desa lebih memilih untuk tinggal di desa dan mengembangkan potensi desa yang ada.

\section{KESIMPULAN}

Pengelolaan kawasan Desa Sukarara secara ekowisata dapat dikatakan berhasil memberikan dampak positif baik bagi warga desa, kehidupan social warga desa, perekonomian warga dan pelestarian lingkungan serta budaya local. Masyarakat semenjak berperan aktif dalam pengelolaan desa Sukarara secara ekowisata semakin paham akan pentingnya menjaga kelestarian lingkungan. Pengelolaan kawasan wisata secara ekowisata terbukti mampu memberi lapangan kerja baru bagi warga desa sehingga mampu mengurangi jumlah warga yang pergi keluar negeri menjadi Tenaga Kerja Indonesia.

\section{DAFTAR PUSTAKA}

Fennel David, Ecotourism, New York, Routledge, 2008

Fennel David, Dowling Ross, 2003. Ecotourism Policy and Planning, Cambridge, CABI Publishing.

Rosida Idah, 2014. Partisipasi Pemuda Dalam Pengembangan Kawasan Ekowisata dan Implikasinya Terhadap Ketahanan Masyarakat desa, Jurnal Ketahanan Nasional,

Ni Wayan Sri Agustini, I Made Adikampana, 2014. Pemberdayaan Masyarakat dalam Proses Pengembangan Ekowisata Taman Sari Buwana di Desa Tunjuk Tabanan Bali, Jurnal Destinasi Pariwisata Universitas Udayana Bali.

Retno Manuhoro Setyowati.2010. trategi Komunikasi yang Mendukung Perkembangan Pariwisata Berbasis Ekonomi Kerakyatan, Universita Semarang,

Nurpeni, 2015. Partisipasi Masyarakat dalam Pelaksanaan Pengembangan Kawasan Ekowisata, Jurnal Kajian Politik dan Masalah Pembangunan Universitas Nasional

Mochamad Widjanarko, Dian Wismar' ein, 2011. Identifikasi Sosial Potensi Ekowisata Berbasis Peran Masyarakat 
Lokal, Jurnal Psikologi Universitas Diponegoro

Ni Luh Putu Agustini Karta, I Ketut Putra Suarthana. 2014. Strategi Komunikasi Pemasaran Ekowisata Pada Destinasi Wisata Dolphin Hunting Lovina, Jurnal Management Strategi Bisnis dan Kewirausahaan STIE Triatma Mulya.

Ahmad Rosyidi Syahid, 1999. Ecotourism, Pariwisata Berwawasan Lingkungan, Makalah pada penataran dosen dan tenaga pengajar bidang pariwisata, Direktorat Perguruan Tinggi Swasta Departemen Pendidikan dan Kebudayaan, Cisarua. 